\title{
MARKETING TREŚCI W PROMOCJI GOSPODARSTW AGROTURYSTYCZNYCH
}

\author{
Karol Król \\ Uniwersytet Rolniczy im. Hugona Kołłątaja w Krakowie \\ Wydział Inżynierii Środowiska i Geodezji
}

\begin{abstract}
Streszczenie: Marketing treści (content marketing) jest stosunkowo nowym pojęciem, które szybko zyskało dużą popularność. Obejmuje spektrum działań, których zadaniem jest pozyskanie klientów przy pomocy odpowiednio przygotowanych treści. Celem pracy jest ocena zasadności podejmowania działań w obszarze marketingu treści w promocji agroturystyki. Ocenie poddano wybrane parametry ilościowe charakteryzujące jakość treści publikowanych na stronach internetowych gospodarstw agroturystycznych. Pomiary wykonano w zbiorze 209 witryn przy pomocy wybranych aplikacji automatyzujących testy. Badania przeprowadzono $\mathrm{w}$ trzech etapach. W pierwszym podjęto próbę pomiaru widoczności witryn w Internecie. W drugim oceniono wybrane parametry techniczne formatowania treści i jakość metainformacji oraz dokonano inwentaryzacji komponentów wchodzących w skład witryn. W ostatnim etapie odnotowano ilość zduplikowanej i unikalnej treści, a także przeciętną liczbę słów na każdej stronie. Wykazano, że witryny gospodarstw agroturystycznych są w większości niewidoczne w wynikach wyszukiwania, charakteryzują się niewielką liczbą wyświetleń i są mało rozbudowane (ubogie w treści). Wymagają zatem podjęcia działań z zakresu content marketingu.
\end{abstract}

Słowa kluczowe: promocja agroturystyki, przydatne treści, strategia marketingowa, widoczność w sieci, zaangażowanie odbiorcy

DOI: $10.17512 /$ znpcz.2018.1.14

\section{Wprowadzenie}

Agroturystyka to forma wypoczynku w gospodarstwie rolnym, w którym produkcja roślinna i zwierzęca wraz $\mathrm{z}$ otoczeniem infrastrukturalnym, przyrodniczym i kulturowym stanowi atrakcje dla turystów (Jalinik, Ziółkowski (red.) 2007, s. 12). Ma ona przeważnie zindywidualizowany charakter i jest adresowana do osób zainteresowanych specyfiką usług oferowanych przez wiejskie gospodarstwa domowe (Ciepiela, Jankowski, Sosnowski 2009, s. 123-134). Agroturystyka stwarza lepsze możliwości wykorzystania zasobów produkcyjnych gospodarstw wiejskich i stanowi jedną z form pozarolniczej aktywności gospodarczej mieszkańców wsi, przez co może wpływać na poprawę sytuacji dochodowej ludności wiejskiej (MarksBielska, Babuchowska 2013, s. 141-150).

Agroturystyka cieszy się rosnącym zainteresowaniem zarówno po stronie popytu, jak i podaży. Wzrasta bowiem nie tylko liczba gospodarstw agroturystycznych i miejsc noclegowych, ale także liczba udzielonych noclegów (Karbowiak 2014, s. 33-44). W miejscowościach o dużym potencjale turystycznym, gdzie jest duża konkurencja, ale także w regionach mniej atrakcyjnych turystycznie, szczególnego 
znaczenia nabierają działania zmierzające do rozpropagowania oferty wśród potencjalnych nabywców (Ciepiela, Jankowski, Sosnowski 2009, s. 123).

Zmiany w konsumpcji treści wymusiły na przedsiębiorstwach istotne modyfikacje działań marketingowych. Działania te, oparte na paradygmacie marketingu transakcyjnego, ewoluowały w kierunku marketingu relacji, marketingu menedżerskiego (ang. managerial marketing) i orientacji na klienta. Działania reklamowe, kluczowe niegdyś dla kampanii promocyjnych, charakteryzuje obecnie malejąca skuteczność - „W czasach, w których urządzenie mobilne stało się podstawowym punktem styku odbiorcy $z$ treścią, pojawił się trend minimalistyczny, który pociągnął za sobą istotne zmiany" (Dylik-Ostrowska 2016, s. 12). Dotyczą one nie tylko samej treści, ale także formy jej przekazu. Czynnikiem, który w największym stopniu odpowiada za zachodzące zmiany, są innowacje wprowadzane w obszarze infotechnologii - „organizacje zostały zmuszone do optymalizowania posiadanych zasobów na podstawie nowoczesnych technologii teleinformatycznych, które zrewolucjonizowały proces komunikacji przedsiębiorstwa z rynkiem" (Witczak 2014, s. 21). Nie bez znaczenia jest także nadmiar przekazów reklamowych ograniczający czas i miejsce emisji innych treści (Nowacki 2013, s. 403-416).

Reklama w Internecie cieszy się rosnącą popularnością. Reklamodawcy wydali w 2015 roku na promocję w polskim Internecie ponad 3 mld zł. To 20-procentowy wzrost w skali roku (Dwornik 2016, s. 24). Według przewidywań ekspertów w kolejnych latach wydatki na reklamę w sieci przekroczą te na reklamę w telewizji, a Internet stanie się największym medium reklamowym świata (Ziemkowska 2016, s. 12). Jednocześnie społeczeństwo funkcjonujące w przestrzeni przesyconej informacją stało się sceptyczne wobec treści promocyjnych (Brzeziński, Ciechanek 2016, s. 14-17). R. Nowacki zauważył, że „coraz większa liczba otaczających konsumenta przekazów, ich zróżnicowanie, ekspansja w środkach masowego przekazu wywołują uczucie przesytu" (Nowacki 2013, s. 414). Nasycenie mediów działaniami reklamowymi wywołuje szum informacyjny, szum reklamowy (ang. advertising clutter, promotional clutter), co ogranicza skuteczność oddziaływania przekazów. Ponadto „użytkownicy sieci wypracowali mechanizmy pozwalające na unikanie komunikacji marketingowej" (Brzeziński, Ciechanek 2016, s. 14). Wszystko to skłania do poszukiwania nowych dróg dotarcia do odbiorców (Nowacki 2012, s. 55-70). Współczesnego konsumenta charakteryzuje bowiem odwaga, świadomość oczekiwań, ciekawość nowości, ale także „wysoki poziom wymagań oraz upraszczanie decyzji, w których nierzadko kieruje się wyobrażeniami, w tym wizerunkiem marki” (Tarczydło 2015, s. 340). M. Łodyga wykazał, że „polski użytkownik Internetu jest wybitnie antyreklamowy" (Lodyga 2017, s. 70). W szybkim tempie rośnie liczba użytkowników programów blokujących prezentację reklam. Zwrócił uwagę, że „W nieodległej przyszłości marketing nie będzie zawierał w sobie klasycznej reklamy, lecz stanie się wyłącznie content marketingiem" (Lodyga 2017, s. 71). Marketing treści jest zatem odpowiedzią na niechęć do reklamy - ,pociąga to za sobą konieczność tworzenia, a następnie dystrybucji takich informacji, które wprowadzą odbiorcę w obszar marki, produktu czy usługi, której jest tematem" (Świeczak 2013, s. 16). 
Celem pracy jest ocena zasadności podejmowania działań w obszarze marketingu treści w promocji gospodarstw agroturystycznych.

\section{Marketing menedżerski i zarządzanie marketingowe}

Marketing, będąc zbiorem zasad postępowania określających ogólną fillozofię działania przedsiębiorstwa, jest zarazem jedną z funkcji organizacyjnych, która stanowi dziedzinę wyspecjalizowanego zarządzania (Zajkowska 2015, s. 360). Odgrywa kluczową rolę w budowaniu i utrzymywaniu przewagi konkurencyjnej. Bez względu na to, czy jest on traktowany jako funkcja przedsiębiorstwa, czy też koncepcja zarządzania, rezultatem jego stosowania jest poprawa wyników finansowych przedsiębiorstwa (Radkowska, Radkowski, Sobotkiewicz 2009, s. 3).

Marketing menedżerski (ang. managerial marketing) to podejście do marketingu tworzące współcześnie główny nurt myśli marketingowej. Menedżerskie podejście do marketingu jest oparte na koncepcji marketingowej, orientacji marketingowej i orientacji na klienta. Szczególnie istotny wpływ na rozwój marketingu menedżerskiego wywarły środowiska biznesowe, zainteresowane uczynieniem z marketingu praktycznego narzędzia w rękach menedżerów (Kamiński 2016, s. 6). Równolegle stosowane jest także pojęcie zarządzania marketingowego (ang. marketing management) (Shaw, Jones 2005, s. 239), które bywa postrzegane jako subdyscyplina zarządzania (Cyfert i in. 2014, s. 44). Zarządzanie marketingowe jest normatywną nauką obejmującą skutecznie kreowanie i oferowanie wartości w celu stymulowania pożądanych transakcji (Prymon 2001, s. 78). Można je rozpatrywać jako uporządkowany przegląd zagadnień osiągania specyficznych reakcji rynkowych innych podmiotów przez kreowanie i oferowanie wartości (Zajkowska 2015, s. 360). Stanowi jedną z wielu możliwych form zarządzania przedsiębiorstwem (Wąsikowska 2015, s. 145).

Szczególną cechą marketingu menedżerskiego jest jego powiązanie ze ścisłym kontekstem zarządzania przedsiębiorstwem. Marketing traktowany jest tu przede wszystkim jako funkcja zarządzania (funkcjonalny obszar biznesu), za której realizację jest odpowiedzialny dział marketingu w przedsiębiorstwie (Kamiński 2016, s. 10). W takim modelu zarządzania problemy marketingowe są rozpatrywane z punktu widzenia menedżera marketingu, który odpowiada za proces zarządzania marketingowego (ang. process of marketing management), rozumiany jako „ciąg działań i decyzji zmierzających do ustalenia i efektywnego wypełnienia celów rynkowych przedsiębiorstwa przebiegających zgodnie z marketingowymi zasadami postępowania" (Niestrój 1998, s. 193). Zarządzanie marketingowe polega na planowaniu marketingowym, organizowaniu, realizacji funkcji marketingu $\mathrm{w}$ przedsiębiorstwie, motywowaniu wykonawców oraz kontrolowaniu wykonania planu. Zarządzanie marketingowe służy zdobyciu jak najlepszej pozycji rynkowej dzięki odpowiedniemu zaplanowaniu, a następnie wykorzystaniu elementów marketingu mix oraz innych działań marketingowych, a także pozostałych zasobów przedsiębiorstwa. Ważnym aspektem tego zarządzania jest również umiejętne kierowanie, monitoring oraz kontrolowanie realizowanych działań (Zajkowska 2015, s. 360). 
W procesie zarządzania marketingowego menedżerowie podejmują różnorakie decyzje. Podstawą ich trafności jest rzetelna i wiarygodna informacja, będąca wynikiem prowadzonych badań marketingowych. Analityka internetowa, zbieranie i gromadzenie informacji o preferencjach i oczekiwaniach klientów, a także poczynaniach konkurentów stały się obecnie priorytetem (Radkowska, Radkowski, Sobotkiewicz 2009, s. 3).

\section{Marketing treści}

Marketing treści (ang. content marketing) jest stosunkowo nowym pojęciem, które szybko zyskało dużą popularność (Sitarski, Ścibisz, Pięta 2016, s. 168-178). Obejmuje spektrum działań, których zadaniem jest pozyskanie klientów przy pomocy odpowiednio przygotowanych treści. Definiowany jest jako sztuka identyfikowania i rozumienia potrzeb danej grupy konsumentów oraz ich umiejętnego zaspokajania. Stanowi część wspólną dwóch elementów: treści, które produkują marki, oraz treści, których potrzebują konsumenci (Kubik-Przybył 2016, s. 4). Marketing treści to jedyna gałąź marketingu, „w której komunikat, którego forma ma charakter komercyjny, ma na tyle silny potencjał, że jest on aktywnie poszukiwany przez konsumenta, do którego jest kierowany" (Świeczak 2013, s. 18). Jako działanie jest znany od lat, bowiem konsumenci od zawsze poszukiwali przydatnych treści.

Content marketing to konsekwentnie realizowana strategia, nie zaś działania podejmowane doraźnie. Polega bowiem na stałym generowaniu treści. To z kolei wymaga systematyczności, dużej wiedzy merytorycznej i umiejętności ich dopasowywania do miejsca, formy i czasu (Skrobich 2016, s. 84-92). Wyniki badań wskazują, że ma on zdecydowanie większy wpływ na konsumentów niż tradycyjna reklama (Świeczak 2013, s. 19). Wysokiej jakości tekst, wzbogacony grafiką i materiałami wideo, może wygenerować ruch na stronie, bowiem „content marketing tworzy wartość i pomaga ludziom" (Świeczak 2013, s. 24). Ponadto sprawia, że to odbiorcy przejmują na siebie ciężar promocji (Chochołowski 2017, s. 10-19).

Content marketing jest wykorzystywany do kreowania wizerunku, wspierania pozostałych działan marketingowych (budowy skali i zasięgu) oraz wzmocnienia sprzedaży (cele: wizerunkowy i sprzedażowy), przy czym efekt sprzedażowy jest tu postrzegany jako konsekwencja budowania określonego wizerunku (Chochołowski 2017, s. 10-19). Marketing treści integruje działania, które jeszcze do niedawna były wykonywane oddzielnie - łączy dziennikarstwo z wiedzą, jak tworzyć i promować treści oraz jak analizować wyniki podjętych działań. Wymaga znajomości zagadnień z zakresu optymalizacji zarówno witryn internetowych, jak i treści, a także mediów społecznościowych, socjologicznych, psychologicznych, wreszcie projektowych, inżynierskich (Rowley 2008, s. 517; Król 2016, s. 84).

Podstawą content marketingu są treści przydatne dla grupy docelowej, naturalne, wiarygodne, niepowtarzalne, staranne, utworzone w oparciu o analizy potrzeb klientów, nie zaś treści generowane masowo, pod wpływem mody czy też własnych przekonań - „najlepsze treści nie mają terminu ważności, a ślad po nich zostaje w sieci" (Milena Majchrzak, za: Grzybowska 2017, s. 47). W marketingu 
treści istotna jest jakość i potrzeby odbiorców - ich zainteresowania, oczekiwania, wiek i status społeczny. Wszystko to powinno stanowić podstawę dla właściwej treści; warunkuje dobór słów, język i styl wypowiedzi, wreszcie formę prezentacji. Zadaniem treści jest budowanie relacji, zaangażowanie odbiorcy, wywołanie emocji, przykuwanie uwagi.

W marketingu treści wyróżnia się kilka zasadniczych typów treści: (1) evergreen content - przydatne i długo lub zawsze aktualne (ponadczasowe), przez co generują ruch organiczny; (2) breaking news - gorące tematy, nawiązujące do najświeższych wydarzeń, przykuwające uwagę, generują duży ruch, jednak o relatywnie krótkiej żywotności; (3) cyclical content, poświęcone wydarzeniom, zjawiskom, trendom, które odbywają się cyklicznie lub które można prognozować, przewidywać. Nie należy jednak zapominać, że „,content marketing to treści realizujące cel biznesowy" (Stawarz-Garcia 2017, s. 48). Podstawą marketingu treści jest strategia określająca, jakie treści, kiedy i jak często są adresowane do wybranych grup docelowych. Wymaga to przygotowania precyzyjnego profilu konsumenta, tzw. persony (ang. customer engagement modeling) (Ratuszniak 2016, s. 7-14). Content marketing to tworzenie treści zgodnych ze strategią i ich właściwa dystrybucja, a także analiza kluczowych wskaźników efektywności (ang. key performance indicators - KPI), bowiem oprócz tworzenia rzetelnych treści ważne jest skuteczne i umiejętne zarządzenie tymi treściami (Świeczak 2013, s. 19). B. Stawarz-Garcia (Stawarz-Garcia 2017, s. 45) wymieniła błędy najczęściej popełniane w marketingu treści: budowa treści w oparciu o produkt, a nie prezentacja świata produktu, tj. uporczywa prezentacja produktu i natarczywa sprzedaż (styl akwizycyjny), brak zapoznania się z potrzebami grupy docelowej, brak charakterystyki potencjalnych klientów (portretu, persony), lekceważenie kwestii technicznych z zakresu SEO, tworzenie przeciętnych, „szarych” treści (powielanie) oraz brak koncentracji na budowaniu relacji.

\section{Materiały i metody}

Badania polegały na ocenie wybranych parametrów ilościowych charakteryzujących jakość treści publikowanych na stronach internetowych gospodarstw agroturystycznych. Badania przeprowadzono w formie audytu wstępnego treści, który stanowić może podstawę dla dalszej oceny jakościowej. Pomiary wykonano przy pomocy wybranych aplikacji automatyzujących testy (Tabela 1), w zbiorze 209 witryn, których adresy pozyskano 24 maja 2017 r. z jednego z ogólnopolskich katalogów witryn. Do badań zakwalifikowano tylko takie witryny, które zostały opublikowane $\mathrm{w}$ domenie krajowej najwyższego poziomu (domena abonamentowa „.pl”, ccTLD - ang. country code top-level domain). Przyjęto bowiem założenie, że właściciele domen abonamentowych przykładają większą wagę do techniki wykonania witryn i jakości publikowanych treści. 
Tabela 1. Aplikacje wykorzystane w ocenie treści

\begin{tabular}{|l|l|}
\hline $\begin{array}{l}\text { Aplikacja testująca } \\
\text { (adres internetowy } \\
\text { lub rodzaj aplikacji) }\end{array}$ & Mierzone (identyfikowane) atrybuty witryn \\
\hline $\begin{array}{l}\text { SEO Spider } \\
\text { Screaming Frog } \\
\text { (desktop) }\end{array}$ & $\begin{array}{l}\text { Inwentaryzacja części składowych witryny. Pomiar } \\
\text { ilościowy i jakościowy (metainformacje, formatowanie } \\
\text { tekstu). }\end{array}$ \\
\hline $\begin{array}{l}\text { Semstorm } \\
\text { (semstorm.com) }\end{array}$ & $\begin{array}{l}\text { Pomiar m.in. zasięgu witryny (statystyki odwiedzin, słowa } \\
\text { kluczowe). Ocena jakości witryny oraz potencjału słów, } \\
\text { na jakie jest widoczna w wynikach wyszukiwania. }\end{array}$ \\
\hline $\begin{array}{l}\text { SimilarWeb } \\
\text { (browser plugin) }\end{array}$ & $\begin{array}{l}\text { Pomiar zasięgu witryny, identyfikacja źródeł ruchu, } \\
\text { estymacja statystyk użytkowania. }\end{array}$ \\
\hline $\begin{array}{l}\text { Siteliner } \\
\text { (siteliner.com) }\end{array}$ & $\begin{array}{l}\text { Pomiar wybranych atrybutów treści, w tym: } \\
\text { zduplikowanej, wspólnej i unikalnej treści, } \\
\text { a także liczby słów na stronie. }\end{array}$ \\
\hline $\begin{array}{l}\text { Webspeed Intensys } \\
\text { (webspeed.intensys.pl) }\end{array}$ & $\begin{array}{l}\text { Ocena objętości tekstu względem kodu } \\
\text { (Text to HTML Ratio, THR). }\end{array}$ \\
\hline $\begin{array}{l}\text { Code to Text Ratio } \\
\text { (webanaliza.pl) }\end{array}$ & \multicolumn{1}{|l|}{. }
\end{tabular}

Źródło: Opracowanie własne

Badania przeprowadzono $\mathrm{w}$ trzech etapach. W pierwszym podjęto próbę oceny oglądalności i widoczności badanych witryn w Internecie. Do tego celu wykorzystano aplikację SimilarWeb (pomiar użytkowania witryn w okresie od kwietnia do września 2017 r.) oraz Semstorm (pomiar użytkowania witryn w okresie od stycznia do października 2017 r.), przy czym różny okres pomiaru wyniknął z warunków użytkowania bezpłatnej wersji aplikacji SimilarWeb. W drugim etapie dokonano inwentaryzacji komponentów wchodzących w skład witryn oraz oceniono wybrane parametry techniczne związane $\mathrm{z}$ formatowaniem treści oraz jakością metainformacji, w tym: długość tytułu (ang. title tag), opis i słowa kluczowe (ang. meta description tag, meta keywords), a także formatowanie treści (wybrane atrybuty z zakresu SEO). W ostatnim etapie zweryfikowano wielkość wskaźnika Text to HTML Ratio, określanego także jako code to text ratio (przyjęto wartość referencyjną rzędu 20\%), stanowiącego procentowy stosunek objętości tekstu (text content size) do objętości kodu (total HTML size). Ponadto dokonano pomiaru wybranych atrybutów treści, w tym: zduplikowanej i unikalnej treści, a także przeciętnej liczby słów na stronie, przy pomocy aplikacji Siteliner.

$\mathrm{W}$ ocenie metainformacji przyjęto kryterium długości tytułu strony (title tag), wynoszące około 65 znaków, przy czym identyfikowano opisy dłuższe, w części niewidoczne w wynikach wyszukiwania Google SERP, oraz krótkie, złożone z co najwyżej 30 znaków. Zaleca się bowiem, aby długość tytułu mieściła się w przedziale od 65 do 70 znaków (ok. 600 px). Długość opisu strony (meta description tag) weryfikowano według wytycznych przyjętych w aplikacji SEO Spider (70-156 znaków). 


\section{Wyniki i wnioski}

Statystyki użytkowania testowanych witryn nie są imponujące. Pomiary wykonane przy pomocy narzędzia Semstorm wskazują, że „ruch” (parametr „Ruch w Semstorm") w przypadku 181 witryn spośród 209 (86,6\%), w okresie od 1 stycznia 2017 r. do 1 października 2017 r., był mniejszy od 200 jednostek, co oznacza, że był znikomy. Jedynie dla 3 witryn był on liczony w tysiącach. Ponadto testowane witryny znajdowały się na odległych miejscach w wynikach wyszukiwania. Aż 28 z nich w ogóle nie było widocznych na pierwszej zakładce wyników organicznych Google (SERP) na żadną kombinację słów kluczowych. Kolejnych 90 witryn było widocznych na pierwszej zakładce jedynie po wpisaniu kilku wybranych kombinacji słów kluczowych, przy czym nie weryfikowano ich trafności. Potencjalnie zatem mogą one generować tzw. „krótkie kliknięcia”, tj. wejścia o dużym współczynniku odrzuceń (niezgodne z oczekiwaniami użytkownika). Wszystko to świadczy o tym, że badane witryny są mało widoczne dla użytkowników w wynikach wyszukiwania i zasadne jest podjęcie działań z zakresu marketingu treści.

Wyniki pomiarów wykonane przy pomocy SimilarWeb potwierdzają wyniki uzyskane przy pomocy aplikacji Semstorm, choć są one wybrakowane, bowiem w 128 przypadkach, co stanowiło $61 \%$ zbioru, wyniki pomiaru były niedostępne. Podczas testów potwierdzono zatem wyniki badań witryn internetowych gospodarstw agroturystycznych polskich i słowackich, przeprowadzonych przez Króla i Halvę (Król, Halva 2017, s. 50-59), którzy zwrócili uwagę, że aplikacja SimilarWeb ma niedostatecznie spenetrowane zasoby polskiego Internetu oraz trudności z estymacją statystyk oglądalności dla witryn, które odnotowują niewielki ruch, oraz takich, które charakteryzuje niewielka widoczność w Internecie.

Witryny z testowanego zbioru są relatywnie niewielkie. Odnotowano 106 witryn (około 51\%), które były złożone z kilku lub kilkunastu stron, i 82 witryny (około 40\%) złożone z kilkudziesięciu stron (plików HTML). Ponadto w trakcie inwentaryzacji zasobów odnotowano jedynie 44 witryny złożone z ponad 500 części składowych (plików HTML, CSS, JS, plików graficznych i innych). Świadczy to o zasadności podjęcia działań content marketingowych, w szczególności z zakresu rozbudowy witryny (treści). Parametr „,wielkości witryny”, wyrażony w tym przypadku liczbą stron, może być w wybranych przypadkach mylący, bowiem w Internecie panuje trend projektowy one-page design (cała treść na jednej stronie). Jest on jednak rzadko wykorzystywany w projektach witryn gospodarstw agroturystycznych. W zbiorze testowanych witryn odnotowano jeden taki przypadek.

Braki tytułów (title tag) odnotowano jedynie na stronach 19 witryn (poszczególne witryny składają się ze stron, dana witryna może być zatem złożona z jednej lub kilkuset i więcej stron). W przypadku 108 stron odnotowano przekroczenie ich zalecanej długości. Na takiej samej liczbie stron odnotowano zbyt krótkie tytuły, często przyjmujące postać jednego słowa. W jednym i w drugim przypadku tak skonstruowane nagłówki wymagają optymalizacji. W licznych przypadkach optymalizacji wymagały także metaopisy witryn (meta description tag). Brakowało ich 
na stronach 114 witryn. Z kolei na stronach 85 witryn były one zbyt dhugie lub zbyt krótkie. Ponadto odnotowano liczne braki słów kluczowych (meta keywords), liczne braki nagłówków (H1) oraz braki tekstu alternatywnego plików graficznych (alt tag).

W zbiorze badanych witryn zidentyfikowano 114 (54\%) według testu Webspeed Intensys oraz aż 167 (80\%) według testu Webanaliza.pl, które miały niekorzystny stosunek treści do kodu (THR mniejszy niż 20\%). Optymalną wartość wskaźnika Text to HTML Ratio, wynoszącą ponad $30 \%$, odnotowano w przypadku 38 witryn $\mathrm{w}$ teście Webspeed Intensys oraz w przypadku jedynie 12 witryn w teście Webanaliza.pl. Istnieje zatem potrzeba uzupełnienia treści na testowanych stronach.

Wyniki pomiarów przeprowadzonych przy pomocy aplikacji Siteliner pokazują, że badane strony są ubogie w treści. Statystyki ilości i struktury tekstu dostępne były w przypadku 200 witryn. Brak dostępu do pozostałych wynikał m.in. z konfiguracji zapisanych w pliku 'robots.txt'. W zbiorze badanych witryn odnotowano 3, które były pozbawione treści (np. Orlickachata.pl). Przygotowanie witryny w całości, w oparciu o pliki graficzne (tekst w formie grafiki) jest rozwiązaniem niewłaściwym. Może to mieć negatywny wpływ na miejsce witryny w wynikach wyszukiwania. Badania pokazują bowiem, że wyszukiwarki preferują witryny bogate w treści. Na stronach internetowych znajdujących się w czołówce wyników wyszukiwania Google SERP odnotować można średnio około 2400 słów, przy czym w pierwszej dziesiątce wyników wyszukiwania znajdują się zwykle witryny prezentujące treści złożone $\mathrm{z}$ około 2000 słów. Ponadto istnieje korelacja pomiędzy ilością treści a liczbą odwołań, które do niej prowadzą (Patel 2012).

Jedynie na dwóch witrynach gospodarstw agroturystycznych odnotowano średnio ponad 1000 słów na stronie (Sokolec.pl oraz Pyzowka.pl). Najwięcej odnotowano witryn ubogich $\mathrm{w}$ treści, w przypadku których na stronę przypadało średnio mniej niż 500 słów. Takich witryn odnotowano 183 (91,5\%), z czego aż 112 (56\%) prezentowało na stronach średnio jedynie 200 słów. W tym miejscu należy podkreślić, że liczone były także słowa, które nie składały się na właściwą treść, lecz stanowiły opis zawarty w stopce witryny, $\mathrm{i}$ inne.

Aplikacja Siteliner wykorzystuje w ocenie treści moduł antyplagiatowy Copyscape. Wysoką unikalność treści, wynoszącą ponad 75\%, odnotowano w przypadku 48 witryn (24\%). Wysoki odsetek zduplikowanej treści, wynoszący ponad $40 \%$, odnotowano w przypadku 10 witryn. Wyniki te potwierdzają potrzebę rozbudowy badanych witryn o treści.

\section{Podsumowanie}

Przeprowadzone badania miały charakter ilościowy i dały pewien pogląd na jakość witryn internetowych gospodarstw agroturystycznych. Potwierdziły ich znikomą widoczność w Internecie, potrzebę optymalizacji wybranych parametrów technicznych oraz uzupełnienia treści (wypełnienia treścią).

Content marketing może służyć do budowania lejka sprzedażowego, wygenerowania ruchu oraz dywersyfikacji źródeł tego ruchu, zwłaszcza organicznego. Zadaniem treści jest zatrzymanie użytkownika i wygenerowanie tzw. „długiego kliknięcia”, tak aby odbiorcy poświęcili czas na zapoznanie się z danym przekazem 
i w konsekwencji wykonali oczekiwaną czynność, co określane jest mianem konwersji celu (Król 2017, s. 33).

Agroturystyka może być uznana za branżę produktową, w której szczególne znaczenie ma prezentacja oferty, przez co trudno jest prowadzić działania content marketingowe. W pewnym zakresie działania te może ułatwić specjalizacja gospodarstwa, np. uprawowa, jeździecka lub kulinarna, najlepiej wypływająca z zainteresowań osobistych gospodarzy. Badania pokazały bowiem, że najlepiej konwertują (generują największy ruch) treści poradnikowe, zatytułowane w odpowiedni sposób np. 5 sposobów na udany sernik. Gospodyni poleca!. Może to stanowić pewną inspirację dla treści, która może wygenerować ruch na stronie. Specjaliści podkreślają: „czytelnicy kochają konkretne przykłady - oczywiście te, których prawdziwość można zweryfikować” (Krupa 2017, s. 57). Tak zredagowany artykuł powinien być zatem uzupełniony autorską fotografią i materiałem wideo. Powinien być także zakończony sentencją zapraszającą na lekcje wypieków prowadzone przez gospodynię. Przytoczony przykład pozwala zauważyć trudności związane z prowadzeniem działań związanych z marketingiem treści, które wymagają zaangażowania, kreatywności, wiedzy i wytrwałości.

\section{Literatura}

1. Brzeziński T., Ciechanek Ł. (2016), Content marketing odpowiedzią na współczesne realia reklamowe, [w:] Konsumpcja treści online a marketing. Raport IAB Polska, ICAN Institute, Warszawa, s. 14-17.

2. Chochołowski B. (2017), Co się sprawdza w content marketingu? Eksperci oceniaja, [w:] Content marketing. Raport, Interaktywnie.com, https://interaktywnie.com/.../159-raportinteraktywnie-com-content-marketing-2017 (dostęp: 01.10.2017), s. 10-19.

3. Ciepiela G.A., Jankowski K., Sosnowski J. (2009), Promocja produktów agroturystycznych gospodarstw rolnych regionu siedleckiego, „Wieś i Rolnictwo”, nr 3(144), s. 123-134.

4. Cyfert S., Dyduch W., Latusek-Jurczak D., Niemczyk J., Sopińska A. (2014), Subdyscypliny $w$ naukach o zarzadzaniu - logika wyodrębnienia, identyfikacja modelu koncepcyjnego oraz zawartość tematyczna, „Organizacja i Zarządzanie”, nr 1(161), s. 37-49.

5. Dwornik B. (2016), Raz dźwignia handlu, raz kula w płot. Reklama ma wiele twarzy, [w:] Reklama w Internecie. Raport, Interaktywnie.com, https://goo.gl/ZsN75n (dostęp: 18.10.2017), s. 24-30.

6. Dylik-Ostrowska K. (2016), Specyfika treści internetowych, [w:] Konsumpcja treści online a marketing. Raport IAB Polska, ICAN Institute, Warszawa, s. 12-13.

7. Grzybowska K. (2017), Agencje dobrze ocenilyby wspólpracę z klientami, gdyby nie..., [w:] Content marketing. Raport, Interaktywnie.com, https://interaktywnie.com/.../159-raportinteraktywnie-com-content-marketing-2017 (dostęp: 01.10.2017), s. 45-50.

8. Jalinik M., Ziółkowski R. (red.) (2007), Agroturystyka stan i perspektywy rozwoju, Wydawnictwo Politechniki Białostockiej, Białystok.

9. Kamiński J. (2016), Refleksje nad zakresem nauki o marketingu jako dyscypliny naukowejcz. 1, „Marketing i Rynek”, nr 6, s. 2-12.

10. Karbowiak K. (2014), Rozwój agroturystyki w Polsce w latach 2010-2013, „Zagadnienia Doradztwa Rolniczego", nr 4(78), s. 33-44.

11. Król K. (2016), Globalne zmiany technologiczne i ich wplyw na promocje agroturystyki w Internecie, „Roczniki Naukowe Ekonomii Rolnictwa i Rozwoju Obszarów Wiejskich”, nr 103(3), s. 84-100. 
12. Król K. (2017), Konwersja celu w internetowej sprzedaży produktów turystyki wiejskiej, „Problemy Drobnych Gospodarstw Rolnych - Problems of Small Agricultural Holdings”, nr 2, s. 33-40. DOI: 10.15576/PDGR/2017.2.33

13. Król K., Halva J. (2017), Measuring Efficiency of Websites of Agrotouristic Farms from Poland and Slovakia, „Economic and Regional Studies”, nr 10(2), s. 50-59.

14. Krupa M. (2017), 11 błędów, które nagminnie popetniaja copywriterzy, „Sprawny.marketing”, $\mathrm{nr}$ 2(2), https://sprawnymarketing.pl/bledy-copywriterow/ (dostęp: 17.12.2017).

15. Kubik-Przybył A. (2016), Jak trendy w konsumpcji treści online wplywaja na działania content marketingowe?, [w:] Konsumpcja treści online a marketing. Raport IAB Polska, ICAN Institute, Warszawa, s. 3-8.

16. Łodyga M. (2017), Bądź firma medialna albo płacz nad AdBlockiem!, „Sprawny.marketing”, nr 2(2), https://sprawnymarketing.pl/placz-nad-adblockiem/ (dostęp: 01.02.2018).

17. Marks-Bielska R., Babuchowska K. (2013), Uwarunkowania rozwoju agroturystyki w województwie warmińsko-mazurskim wedtug opinii właścicieli gospodarstw rolnych, „Folia Pomeranae Universitatis Technologiae Stetinensis. Oeconomica", nr 299(70), s. 141-150.

18. Niestrój R. (1998), Proces zarządzania marketingowego, [w:] Altkorn J., Kramer T. (red.), Leksykon marketingu, PWE, Warszawa, s. 193-194.

19. Nowacki R. (2012), Innowacyjność działań reklamowych - przejawy i skutki, „Zeszyty Naukowe Uniwersytetu Szczecińskiego. Problemy Zarządzania, Finansów i Marketingu", nr 26, s. 55-70.

20. Nowacki R. (2013), Percepcja przekazów reklamowych i jej wpływ na zachowania konsumentów w pierwszej dekadzie XXI wieku, „Zeszyty Naukowe Uniwersytetu Szczecińskiego. Problemy Zarządzania, Finansów i Marketingu”, nr 32, s. 403-416.

21. Patel N. (2012), How Content Length Affects Rankings and Conversions, „Quick Sprout”, https://goo.gl/L8P7iA (dostęp: 02.12.2017).

22. Prymon M. (2001), Wspótczesne badania marketingowe, Redakcja Wydawnictw Katolickiego Uniwersytetu Lubelskiego, Lublin.

23. Radkowska J., Radkowski K., Sobotkiewicz D. (2009), Zarządzanie marketingowe przedsiębiorstwem $w$ warunkach gospodarki rynkowej. Wybrane zagadnienia, Państwowa Wyższa Szkoła Zawodowa im. Witelona w Legnicy, Legnica.

24. Ratuszniak B. (2016), Content marketerem może być dziś każdy. Nie każdy potrafi być skuteczny, Interaktywnie.com, https://interaktywnie.com/biznes/artykuly/trendy/contentmarketerem-moze-byc-dzis-kazdy-ale-nie-kazdy-potrafi-byc-skuteczny-253170 (dostęp: 01.10.2017).

25. Rowley J. (2008), Understanding Digital Content Marketing, „Journal of Marketing Management", Vol. 24(5-6), s. 517-540. DOI: 10.1362/026725708X325977

26. Shaw E.H., Jones D.G.B. (2005), A History of Schools of Marketing Thought, „Marketing Theory", Vol. 5(3), s. 39-65. DOI: 10.1177/1470593105054898

27. Sitarski K., Ścibisz M., Pięta S. (2016), Wykorzystanie koncepcji marketingu treści w polskich przedsiębiorstwach - wyniki badań, „Studia Ekonomiczne”, nr 281, s. 168-178.

28. Skrobich L. (2016), Content marketing jako jeden z kluczowych elementów nowoczesnej strategii marketingowej, „Zeszyty Naukowe Politechniki Częstochowskiej. Zarządzanie”, nr 22, s. 84-92. DOI: 10.17512/znpcz.2016.2.07

29. Stawarz-Garcia B. (2017), 5 chybień. Jak naprawić błędy $w$ działaniach content marketingowych, Sprawny.marketing.pl, https://sprawnymarketing.pl/bledy-content-marketingu/ (dostęp: 15.12.2017).

30. Świeczak W. (2013), Content marketing jako istotny element strategii marketingowej instytucji naukowych, „Marketing i Rynek”, nr 10(20), s. 16-24.

31. Tarczydło B. (2015), Inbound Marketing $w$ budowaniu wizerunki marki $w$ Sieci. Studium przypadku, „Zeszyty Naukowe Uniwersytetu Szczecińskiego. Studia i Prace Wydziału Nauk Ekonomicznych i Zarządzania”, nr 2(39), s. 339-352. 
32. Wąsikowska B. (2015), Zastosowanie technik neuronauki poznawczej w zarządzaniu marketingowym, „Zeszyty Naukowe Szkoły Głównej Gospodarstwa Wiejskiego w Warszawie. Polityki Europejskie, Finanse i Marketing", nr 13(62), s. 145-156.

33. Witczak O. (2014), Inbound marketing a koncepcja marketingu relacji, „Studia Ekonomiczne", nr 182, s. 20-29.

34. Zajkowska M. (2015), Marketing zrównoważony - od tradycyjnego do innowacyjnego nurtu zarzadzania marketingowego, „Zeszyty Naukowe Uniwersytetu Szczecińskiego. Problemy Zarządzania, Finansów i Marketingu", nr 41(2), s. 359-370.

35. Ziemkowska D. (2016), Już mamy złote czasy reklamy internetowej w Polsce. A będzie... jeszcze lepiej, [w:] Reklama w Internecie, https://goo.gl/ZsN75n (dostęp:18.10.2017), s. 10-16.

\title{
CONTENT MARKETING IN PROMOTING AGROTOURISTIC FARMS
}

\begin{abstract}
Content marketing is a relatively new concept which quickly gained acceptance. It includes a range of activities whose task is to win customers using properly prepared content. The aim of the paper is to evaluate the rationale for taking actions in the area of content marketing in promoting agrotouristic farms. The study carried out evaluated selected quantitative parameters characterizing the quality of content published on websites of agrotouristic farms. A set of 209 websites was measured using selected applications that automate tests. The research was carried out in three stages. The first measured the visibility of websites on the Internet. In the second, selected technical parameters of content formatting and the quality of meta-information were assessed, and an inventory of components included in the websites was made. In the last stage, the amount of duplicated and unique content and the average number of words on each website were recorded. In conclusion, the study demonstrated that the websites of agrotouristic farms are mostly invisible in search results, have a small number of displays, are poorly developed (poor content), and need optimization. Therefore, it is reasonable to take actions in the area of content marketing.
\end{abstract}

Keywords: involvement of a recipient, marketing strategy, promotion of agrotourism, useful contents, visibility in the network 